ELISA FORTUNATO

University of Bari, Italy

e-mail: elisa.fortunato@uniba.it

\title{
"But Men May Construe Things After Their Fashion": Julius Caesar and Fascism
}

\begin{abstract}
This paper studies censorship and self-censorship in translations during the fascist regime, and the fine boundary between the two (Bonsaver, Fabre, Rundle). It focuses, in particular, on the history, of Shakespeare's Julius Caesar translations released during fascism in Italy. Shakespeare's play was read as an appraisal of the Roman qualities, while the dangerous questions about power and conspiracy that the play contains were ignored. This superficial reading explains why, on the one hand, translations of Julius Caesar increased in the fascist years and, on the other hand, why it was performed only once (in 1935 by Tamberlani). The act of translating is by definition an act of manipulation, ${ }^{1}$ while on the stage theatrical properties (e.g., Julius Caesar's corpse) are not concealable. Examining the translations issued during the regime, and in particular the translators' notes, it is possible to identify a general translation trend that can be interpreted as an act of submission to the dominant thinking (Tymoczko).
\end{abstract}

Keywords: translation, fascism, self-censorship

"Censorship is a particular kind of context, and it foregrounds the always present tension between text and context". ${ }^{2}$

This paper discusses a less blatant form of control, that peculiar phenomenon of self-censorship which took place in Italy during the first decade of the fascist domination (1914-1938), before the racial laws promulgation (1938) when censorship became overt and coercive. In particular, I analyze the reception through translations of the full text of Julius Caesar by William Shakespeare which was

1 S. Bassnett, The Translation as a Writer, London-New York 2008; eadem, Constructing Cultures, Bristol 1998; A. Lefevere, Translation, Rewriting and the Manipulation of Literary Fame, London-New York 2016; L. Venuti, The Translator's Invisibility: A History of Translation, LondonNew York 2008.

2 M. Holquist, Corrupt Originals: The Paradox of Censorship, "PMLA" 1994, no. 109.1, p. 14. 
translated several times during the regime but put on stage only once in 1935 . I argue that two important facts would have made it easily "translatable": Shakespeare's work was a classic and was "universally recognized as such" (as we read in a circular note from the Minister of Popular Culture, Dino Alfieri, to the prefects), ${ }^{3}$ and Caesar being the myth of the Roman spirit. On the other hand, the dangerous question about power which the play contains, and which takes shape on the stage when Caesar's corpse, covered with blood, is shown, is likely to have acted as a powerful reminder of the possibility of a rebellion. It is precisely for this reason that the play was not staged until 1935.

During the Fascist regime, translations became a political issue and were framed in terms of a trade war. The common political discourse was making reference to the import and export of intellectual products and to a "trade balance" which needed to be redressed in favour of Italian intellectual production. More generally, the regime was disturbed by the idea of Italy being an excessively receptive culture, with an exaggerated enthusiasm for all things coming from abroad, with translations being the threatening sign of that very weakness (available data show that Italy published more translations than any other country in the world at the time and that between 1933 and 1934 translations from English tripled). ${ }^{4}$ Despite those concerns, however, the regime was unwilling to stop the translation industry because it could have triggered the exclusion of Italy from the international debate and from a growing business.

The Italian fascist dictatorship had, therefore, an ambiguous attitude towards translations. According to the famous magazine of the publishers' association (Il Giornale della Libreria), the three pillars of the Italian autarchy were: "to give value and power to books and magazines, to exclude things carefully in defence of the national interest, and to absorb all activities, including those coming from abroad, which could contribute to the creation of a modern society". Translating

3 "I. A datare dal 1o aprile c.c. soltanto questo ministero potrà autorizzare la diffusione in Italia delle traduzioni straniere; II. Gli Editori possono inviare a questo Ministero direttamente o a mezzo della Prefettura, nella lingua originale, i libri che intendono tradurre in italiano; III. Questo Ministero farà conoscere all'Editore - tramite la Prefettura competente - il suo giudizio nel termine più breve; [...] V. Sono esclusi dalla preventiva approvazione i trattati puramente scientifici (medicina-ingegneriamatematica-astronomia-botanica-zoologia) e i classici universalmente riconosciuti”; translation: "I. Dating from 1 April of this year only this Ministry may authorize the diffusion of foreign translations in Italy; II. Publishers may send those titles they intend to translate into Italian in the original language directly to this Ministry or through the Prefecture; III. The Minister will notify the Publisher - through the appropriate Prefecture - of its decision with the shortest possible delay; [...] V. Purely scientific treaties (in medicine, engineering, mathematics, astronomy, botany and zoology) and classics universally recognized as such are exempt from such prior approval". Unless otherwise specified, all translations from Italian are mine. For the Italian quotation, see G. Fabre, Fascism, Censorship and Translation, in: Modes of Censorship and Translation. National Context and Diverse Media, F. Billiani (ed.), London-New York 2007, pp. 27-28.

${ }^{4}$ See Ch. Rundle, Translations as a Threat to Fascism, in: Translation and Opposition, D. Rogers, M. Rogers (eds.), Bristol 2011. See also G. Bonsaver, Censorship and Literature in Fascist Italy, Toronto 2007; D. Forgacs, Mass Culture and Italian Society from Fascism to the Cold War, Bloomington 2008. 
novels became one means to "absorb" and "include" the other into Italian culture, a way to "cannibalize" it (to use Bassnett's term).

Broadly speaking, it is possible to divide the period from 1929 to 1943 into two phases. An initial phase when, although with some disapproval regarding the influx of foreign literature, the regime neither cared enough nor was organized enough to attempt to hinder the rapidly increasing inflow. A second phase, from 1935 onwards, when the Press Office became the Ministry for Press and Propaganda, censorship and repression of freedom became more and more common practice. The phase culminated in 1938 with the introduction of the fascist Racial Laws.

Between 1924 and 1925 at least thirteen new translations of Shakespeare's Julius Caesar appeared in print throughout the Italian peninsula; at least forty editions, including new translations and reprints published during Mussolini's twenty-year rule, have survived. In my paper I analyze six translations that appear interesting for their notes and critical introductions. ${ }^{5}$

The fact that Shakespeare's work might find a place in Italian fascism's program of cultural propaganda is not in itself remarkable, this being part of the jingoistic use of the Bard during the regime. Youngsters with their impressionable minds fired up by all the glorified facts about the Regime's radiant legacy would read Shakespeare's Julius Caesar and, according to plan, would come to adore the legendary Roman hero and through him their current day ruler. ${ }^{6}$ Shakespeare's play was read just as a way to glorify the Roman qualities, voluntarily forgetting the dangerous questions about power and conspiracy that the play contains. This superficial reading explains why the play was performed only once (in 1935 by Tamberlani) although Julius Caesar translations increased precisely during fascism.

The act of translating is by definition an act of manipulation while on the stage, the 'props' are not concealable (i.e. Julius Caesar's corpse). There is a deep and complex relationship between theatre and cultural memory: "theatre, as a simulacrum of the cultural and historical process itself, seeking to depict the full range of human actions within their physical context, has always provided society with the most tangible records of its attempts to understand its own operations. It is the repository of cultural memory, but, like the memory of each individual, it is also subject to continual adjustment and modification as the memory is recalled in new circumstances and contexts". ${ }^{7}$ From this point of view, the history of the translations of Shakespeare's Julius Caesar released during fascism could be quite

5 The translations in chronological order: G. Shakespeare, Giulio Cesare, versione e testo a fronte di A. Ricci, Firenze 1924; idem, Giulio Cesare, G.A. Cesareo (transl.), Messina-Roma 1924; idem, Giulio Cesare, a cura di D. Angeli, in: Teatro di Guglielmo Shakespeare, Milano 1924; idem, Giulio Cesare, a cura di A. Avancini, Milano 1925; idem, Giulio Cesare, versione, introduzione e note di R. Piccoli, Firenze 1925; idem, Giulio Cesare, in: Opere complete di Guglielmo Shakespeare, tradotte da A. Muccioli, Firenze 1925; 1936.

6 N. Isenberg, 'Caesar's word against the world'. Cesarism and the Discourses of Empire, in: Shakespeare and the Second World War: Memory, Culture, Identity, I.R. Makaryk, M. McHugh (eds.), Toronto 2012, p. 85.

7 Shakespeare and the Second..., op. cit., p. 3. 
revealing as they help us understand that an apparently contradictory system of surveillance and punishment was in place under the fascist regime.

During the two decades of the Regime, Mussolini used the 'Caesarian model' of leadership as the background for his political project of establishing a 'Modern Roman Empire' and of becoming himself a 'Modern Caesar'. Mussolini formally came to power with the march to Rome which took place from the $22^{\text {nd }}$ to $29^{\text {th }}$ October 1922. It was thought to mirror, even in its itinerary, Julius Caesar's crossing the Rubicon in 49 BC. Mussolini looked at ancient Rome with its romanitas and its powerful armies as models of strength, discipline, and skill. As a consequence of that 'appropriation', Shakespeare's Julius Caesar was included in the middle school curriculum as part of the study of Roman history. Furthermore, Julius Caesar "was considered one of Shakespeare's most accessible plays" ${ }^{\prime}$ with its seemingly stylistic simplicity, and its lack, in comparison to other Shakespeare's plays, of lasciviousness and obscenity. "But more important in the context at hand were Julius Caesar's roots in great Latin texts and its recreation of a chapter in the life of the greatest of Roman heroes". 9

The institutions of censorship failed in understanding the true meaning of the play, getting lost in the complexity of relationships among the characters and of the particular characters' relationship with history. In this play, every character, from Brutus to Cassius, from Caesar to Antony, is torn between public and personal motives. There is always a sense of divergence between the image every character, obliged by the force of circumstances, presents to the world and the reality of what he in fact is (this is true in particular of the male characters). Caesar and Brutus are the most troubled and intense male characters, both of them crushed by the Mechanism of History, which determines their historical role, and which they cannot stop or change. But in most of the Italian translators' notes and critical introductions of those years, Caesar's physical vulnerability inversely mirrors moral grandeur. ${ }^{10}$ As a consequence, the words of Cassius in I.2. 90-131 $1^{11}$ when he starts manipulating Brutus with his bad account of Caesar, were not perceived as a way of belittling Caesar's image, but as Cassius' invention to accomplish his malignant plan.

In particular, it is interesting to underline how Avancini and Piccoli, who both translated Julius Caesar in 1925, felt the urge to add several explanatory notes. So, for example, Avancini glosses lines 97-99 with this explanation: "There is in Cassius, beyond his love for freedom, a sinister and deep envy toward Caesar". ${ }^{12}$ Similarly, Piccoli provides an explanation for lines 110-115, revealing that "This race between Cassius and Caesar is an invention of the poet for the historians'

8 N. Isenberg, 'Caesar's Word against..., op. cit., p. 86.

9 Ibid.

10 Cf. the interesting introduction by Ricci to his translation Giulio Cesare, 1924 (III ed.).

11 All quotations from Julius Caesar are taken from W. Shakespeare, Julius Caesar, D. Daniell (ed.), The Arden Shakespeare, Sydney 2015.

12 "In Cassio, oltre all'amore per la libertà, c'è un bieco e profondo sentimento d'invidia verso Cesare", in: G. Shakespeare, Giulio Cesare, con prefazione e note di A. Avancini, Milano 1925, p. 56. 
record how Caesar had saved his own life and his Commentari, by swimming in the port of Alexandria". ${ }^{13}$

Moreover, in all the critical introductions to the translations issued in the years of Fascism, the tyrannicide is called murder or assassination and Caesar is a hero not a tyrant, which makes Brutus an assassin, not a patriot. The translators are all voluntarily blind to the text's complexities and to the world it creates, the world where all those who rule are weak or ill. The image of illness and the theme of disease run continuously through the play, i.e. Caesar suffers from the "falling sickness", "fever", "deafness", his wife Calphurnia is "sterile", Cassius suffers from "shortsightedness", Casca and Caius Ligarius from "ague", Brutus cannot sleep at night and his wife Portia fears he is ill; Portia herself is running high fever from the wound she has inflicted on herself.

As Cicero remarked to Casca: "Indeed it is a strange-disposed time./But men may construe things after their fashion/Clean from the purpose of the things themselves". ${ }^{14}$ In the strange-disposed time of Fascism the readers of Julius Caesar were guided through the text in order to appreciate "the ruling force of Caesar", "if Caesar dies at the beginning of the third act, [...], his spirit is always there. [...] his very enemies have to admit that he is forever 'alive', august and immortal as Rome spirit itself'. ${ }^{15}$ Muccioli, in the Introduction to his translation published in 1924, goes one step further explaining that the true hero of the play is "Caesar's spirit which powerfully dominates the entire drama" and highlights the way in which Caesar "saved" and "consolidates" the empire. The translator continues by recognising the weaknesses and frailty in Shakespeare's Caesar and carefully confutes all of them: "the Poet shows a man totally different from the actual Caesar". ${ }^{16}$ Muccioli levels the character's complexity and, in doing so, he gives the Italian reader a flat character, who lacks interior dilemma and inner

13 "Questa gara tra Cesare e Cassio è invenzione del poeta: gli storici antichi narrano come Cesare salvasse sè e I suoi Commentari a nuoto nel porto d'Alessandria, onde si deduce la sua perizia di nuotatore", in: G. Shakespeare, Giulio Cesare, versione, introduzione e note di R. Piccoli, Firenze 1925, p. 32.

14 I.3.33-35.

15 "Le creazioni di Shakespeare sono tutte in funzione dell'ispirazione originaria, la potenza dominatrice del genio di Cesare. Perché in questa singolare tragedia, se Cesare muore in principio dell'atto terzo, e prima non apparisce che in una breve scena del primo e in un'altra, un po' più lunga, del secondo atto, pure la sua figura gitta la propria ombra vasta da un capo all'altro della tragedia: egli è presente sempre, anche più quando è assente: non si parla che di lui, non si combatte che per lui, si vince o si muore per lui, i suoi stessi nemici sono costretti, pur dopo averlo trafitto, a confessare ch'egli è sempre vivo, ch'egli è augusto ed eterno come l'anima stessa di Roma", in: Notizia preliminare, in: G. Shakespeare, Giulio Cesare, tragedia tradotta da G.A. Cesareo, Messina-Roma 1924, p. 4. Some of this neds to be integrated into the main text, but in English translation.

16 "Ma vivo o morto Cesare, è il suo spirito che domina potentemente tutto il dramma; nulla si fa, nulla si dice che non sia fatto e detto sotto l'influsso spirituale del grande uomo [...]", "Il Poeta ci presenta un uomo assai diverso e assai distante da ciò che in realtà fu Cesare, la cui figura [...] col trascorrer dei secoli ingigantisce" e poi ancora: "Invece, non può affermarsi che egli non avesse un giusto concetto di Cesare, poiché e in questo suo dramma e in parecchi luoghi degli altri ha dato prova di esser pienamente conscio delle alte qualità morali ed intellettuali di Cesare" (translation: "We cannot affirm that he [Shakespeare] had an unjust concept of Caesar, for in this play and in many passages of others he has given proof of being fully aware of the high moral and intellectual qualities of Caesar"), in: 
world. The language of Shakespeare's Julius Caesar, in all 130 lines he speaks, is always elevated, even when he talks to his wife. He is authoritative, imposing and speaks in aphorisms, ${ }^{17}$ yet "in a play given almost wholly to oratory and persuasion, the titular hero does not persuade". ${ }^{18}$ He depicts himself "constant as the northern star,/Of whose true-fixed and resting quality/There is no fellow in the firmament", ${ }^{19}$ but his constancy does not survive his wife's pleading not to go to the Senate house or Decius' counter-plea. ${ }^{20}$ The scene in which Caesar is persuaded, against his will, to go to the Capitol is indeed revealing. As Calphurnia, shaken by premonitions which the elements confirm, presses him to stay at home, he clings obstinately to his determination repeating the sentence "Caesar shall go forth" three times ${ }^{21}$ but then, after less than eight lines, he acquiesces: "Mark Antony shall say I am not well". ${ }^{22}$ Even if he adds the excuse that it is the frailty of others that has imposed this change of plan - "And for thy humour I will stay at home" 23 - he reveals himself to be less 'consistent' than he wants to be. The arrival of Decius who will change the interpretation of Calphurnia's ill-fated premonitions making them propitious is even more revealing of Caesar's inner war, torn as he is between his ambition of being crowned and his inner uncertainty.

Brutus' rhetoric is also a key aspect of the playtext. Brutus is the counterpart of Caesar as Shakespeare gives him the same, or even more, depth and calibre. His language mirrors his inner dilemma, which is even more excruciating than Caesar's. All the translations released during the fascist regime period largely failed to render his being "with himself at war". ${ }^{24}$ Brutus' inner world is in conflict with itself, he fights the shadow shown by Cassius. ${ }^{25}$ The shadow Cassius creates here means reflection, by a subsidiary and not infrequent use. ${ }^{26}$ Cassius is not projecting Brutus' inner world, but creating a new Brutus, as if he were Brutus' mirror returning him a new image of himself. Muccioli, Cesareo, Piccoli and Ricci had translated "shadow" with the Italian "ombra"27 losing the mirror metaphor, and Angeli and Avancini had chosen the Italian "imagine", which does not render Shakespeare's

G. Shakespeare, Giulio Cesare, in: Opere complete di Shakespeare, tradotte da A. Muccioli, Firenze 1924 (1936), pp. 8-9. Some of this neds to be integrated into the main text, but in English translation.

17 I.e. "Cowards die many times before their deaths;/The valiant never taste of death but once./ Of all the wonders that I yet have heard,/It seems to me most strange that men should fear,/Seeing that death, a necessity end,/will come when I twill come", II.2.32-37.

18 D. Daniell (ed.), Julius Caesar. The Arden Shakespeare, London-New Delhi-New York-Sydney 2015 , s. 47.

19 III.60-62.

20 II.2.

21 II.2.10; II.2.28; II.2.48.

22 II. 2.55 .

23 II. 2.56 .

24 I.2.46.

25 "And it is very much lamented, Brutus,/That you have no such mirrors as will turn/Your hidden worthiness into your eye,/That you might see your shadow [...]", I.2.55-58.

26 Oxford English Dictionary: "5. A reflected image".

27 Meaning the darkness caused by interception of light, a tract of partial darkness produced by a body intercepting the direct rays of the sun or other luminary. 
metaphor either. They all soften the role Cassius plays in the conspiracy and, in doing so, increase that of Brutus.

In II.1. Brutus comes to a decision and speaks out his famous twenty lines:

It must be by his death: and for my part

I know no personal cause to spurn at him

But for the general. He would be crowned:

How that might change his nature, there's the question.

It is the bright day that brings forth the adder,

And that wary walking. Crown him that,

And then I grant we put a sting in him

That at his will he may di danger with.

Th'abuse of greatness is when it disjoins

Remorse from power; and to speak truth of Caesar

I have not known when his affections swayed

More than his reason. But 'tis a common proof

That lowliness is young ambition's ladder

Whereto the climber upward turns his face;

But when he once attains the upmost round

He then unto the ladder turns his back,

Looks in the clouds, scorning the base degrees

By which he did ascend. So Caesar may.

Then, lest he may, prevent. And since the quarrel

Will bear no colour for the thing he is,

Fashion it thus: that what he is, augmented,

Would run to these and these extremities.

And therefore think him as a serpent's egg

Which hatched, would as his kind grow mischievous,

And kill him in the shell (10-34).

Here, Muccioli fails to understand many words (for example, he translates "remorse" with the Italian "rimorso" and not the more accurate "compassione" or "coscienza", ${ }^{28}$ while "turn his face" becomes "muta sembianze"). It should be stressed that the translated text lacks completely performability and speakability and seems to have been written only to be read. Moreover, the translator adds several notes highlighting the lack of cause supporting Brutus' act. ${ }^{29}$ Piccoli, Ricci, and Avancini, on the other hand, produce plain translations, even if the latter uses the notes to repeatedly stress Caesar's leadership qualities. Cesareo and Angeli translate "sting" respectively with "arma" and "dardo" (wound" and "arrow") losing the adder metaphor which is crucial in Brutus" words. In fact, Brutus cannot decide to kill Caesar without creating an image, without thinking about the adder instead of Caesar himself, he needs this metaphor to act, as a con-

28 Oxford English Dictionary: "Remorse: Compassion with an older sense of conscience".

29 I.e. "Non solo Bruto non aveva alcuna particolare ragione d'odio verso Cesare, ma, al contrario, aveva ragione di gratitudine, avendogli Cesare risparmiata la vita dopo Farsaglia; inoltre lo nominò prima pretore nella Gallia Cisalpina, l'anno 46 a.c., e poi in Roma, l'anno 44", in: G. Shakespeare, Giulio Cesare, in: Opere complete di Shakespeare, tradotte da A. Muccioli, Firenze 1924 (1936), pp. 56-57. 
sequence, the choice of translating "sting" with "arma" or a "dardo" testify their misinterpretation of the lines giving the Italian reader-playgoer a flat image of the kaleidoscopic Brutus; Cesareo chooses not to translate the modal verb "So Caesar may". In Shakespeare, Brutus' language shows his inner dilemma which does not fade out with this soliloquy and that will bring him, through the "interim", to the final breakdown which will culminate in his committing suicide. His shadow will destroy him. The shadow mentioned by $\mathrm{Cassio}^{30}$ has the meaning of "reflection" not of "a dark area or shape made by an object blocking rays of light" and it will be this very "shadow", this completely anew Brutus, that will fail, in the end, in his purpose. In the Italian translations released during the fascist regime, only Avancini and Angeli translate "shadow" in its meaning of "reflection", through the Italian "imagine"; even if, it is fundamental to underline, both of them use the Italian "imagine" in the meaning of "worst part of the self".

In the construction of the myth of the Duce, it seems that Shakespeare's Julius Caesar was seen as a useful 'tool', but only as a written text, not on stage; issuing plain, often blunt translations combined with critical introductions which bend the complexity of Julius Caesar to an ethnocentric reduction of the foreign text to target culture, the Italian readers would have certainly seen themselves as the direct heirs of ancient Rome, and Mussolini as their Caesar. In 1935 Nando Tamberlani directed the only Julius Caesar staged during the regime period. The 'stage' was not a theatre but the Basilica of Maxentius, one of the most impressive monuments of the Forum-Palatine complex; the "mis-en-scene was no pictorial reconstruction of ancient Rome, but the very ruins that survived from the ancient city, and were now newly revealed and restored" 31 ; the ideological plan was to create a juxtaposition between the fascist Italy and the Roman empire (the play was staged just before the Italo-Ethiopian war) and, in so doing, to neutralize the subversive and 'dangerous' subjects of the play. The production was a success, "it was intended as an invitation to spend one of the hottest evenings of the summer out of doors in a privileged setting not normally frequented by the working class, [...]. For these workers, an evening spent amidst spectacular archaeological ruins, watching a performance that re-enacted a piece of their cultural history, was in itself perceived as a powerful piece of rhetoric that reiterated Mussolini's call "not to nostalgic contemplation of the past, but hard preparation for the future". ${ }^{32}$

In conclusion, analysing Julius Caesar's translations during the fascist regime ideology emerges as an implicit component of the translation process, at the root of self-censorship. Julius Caesar's translation can be therefore seen, in tune with the latest theoretical debate, not only as a historical object but also as an approach to interpreting a historical subject, in this case study it may cast light on Italian cultural history and provide a fascinating insight into Italian fascist cultural policy.

30 I.2.58.

31 G. Holderness, Julius Caesar: Shakespeare and the Ruins of Rome, in: Shakespeare and the Visual Arts. The Italian Influence, M. Marrapodi (ed.), London-New York 2017, p. 343.

32 N. Isenberg, 'Caesar's word against..., op. cit., p. 92-93. 


\section{References}

Bassnett S., Constructing Cultures, Bristol 1998.

Bassnett S., The Translation as a Writer, London-New York 2008.

Billiani F. (ed.), Modes of Censorship and Translation. National Context and Diverse Media, London-New York 2007.

Bonsaver G., Censorship and Literature in Fascist Italy, Toronto 2007.

Daniell D. (ed.), Julius Caesar. The Arden Shakespeare, London-New Delhi-New York-Sydney 2015.

Fabre G., Fascism, Censorship and Translation, in: Modes of Censorship and Translation. National Context and Diverse Media, F. Billiani (ed.), London-New York 2007, pp. 27-59.

Forgacs D., Mass Culture and Italian Society from Fascism to the Cold War, Bloomington 2008.

Holderness G., Julius Caesar: Shakespeare and the Ruins of Rome, in: Shakespeare and the Visual Arts. The Italian Influence, M. Marrapodi (ed.), London-New York 2017, pp. 90-115.

Holquist M., Corrupt Originals: The Paradox of Censorship, "PMLA" 1994, no. 109.1 , pp. 14-25.

Isenberg N., 'Caesar's word against the world'. Cesarism and the Discourses of Empire, in: Shakespeare and the Second World War: Memory, Culture, Identity, I.R. Makaryk, M. McHugh (eds.), Toronto 2012, pp. 83-105.

Lefevere A., Translation, Rewriting and the Manipulation of Literary Fame, LondonNew York 2016.

Munday J., Using Primary Sources to Produce a Microhistory of Translation and Translators: Theoretical and Methodological Concerns, "The Translator" 2014, no. 20 , p. 1 .

Rundle Ch., Publishing Translations in Fascist Italy, Oxford-Bern-Berlin-Bruxelles-Frankfurt am Main-New York-Wien 2010.

Rundle Ch., Theories and Methodologies of Translation History: the Value of an Interdisciplinary Approach, "The Translator" 2014, no. 20, p. 1.

Rundle Ch., Translations as a Threat to Fascism, in: Translation and Opposition, D. Rogers, M. Rogers (ed.), Bristol 2011, pp. 295-304.

Shakespeare G., Giulio Cesare, A. Ricci (transl.), Firenze 1924.

Shakespeare G., Giulio Cesare, D. Angeli (transl.), in: Teatro di Guglielmo Shakespeare, Milano 1924.

Shakespeare G., Giulio Cesare, G.A. Cesareo (transl.), Messina-Roma 1924.

Shakespeare G., Giulio Cesare, A. Avancini (transl.), Milano 1925.

Shakespeare G., Giulio Cesare, in: Opere complete di Guglielmo Shakespeare, A. Muccioli (transl.), Firenze 1924 (1936).

Shakespeare G., Giulio Cesare, R. Piccoli (transl.), Firenze 1925.

Shakespeare W., Julius Caesar. The Arden Shakespeare, D. Daniell (ed.), LondonNew Delhi-New York-Sydney 2015.

Shakespeare and the Second World War: Memory, Culture, Identity, I.R. Makaryk, M. McHugh (eds.), Toronto 2012.

Venuti L., The Translator's Invisibility: A History of Translation, London-New York 2008. 
Wyke M., Sawdust Caesar: Mussolini, Julius Caesar, and the Drama of Dictatorship, in: Uses and Abuses of Antiquity, M. Biddiss, M. Wyke (eds.), Oxford-Bern-Berlin-Bruxelles-Frankfurt am Main-New York-Wien 1999, pp. 167-186. 